\title{
A reforma agrária no segundo mandato de Fernando Henrique Cardoso
}

\author{
José de Souza Martins
}

\section{0 advento da questão agrária na política do governo}

A política de reforma agrária do segundo mandato presidencial de Fernando $\mathrm{H}$ enrique $\mathrm{C}$ ardoso começou de fato na segunda metade do primeiro mandato, quando $\mathrm{R}$ aul Jungmann foi nomeado para $\mathrm{o} \mathrm{M} \mathrm{i-}$ nistério Extraordinário de $\mathrm{R}$ eformaAgrária, depois $\mathrm{M}$ inistério do $\mathrm{De}$ senvolvimento A grário (M DA), em 1996¹. A s tragédias de C orumbiara, em R ondônia, em 9 de agosto de 1995, e a de Eldorado de $C$ arajás, no Pará, em 17 de abril de 1996, serviram como alerta para o governo e a sociedade de que, apesar das aparências, as tensões no campo estavam em nível explosivo.

Embora as entidades brasileiras devotadas ao tema e as entidades internacionais que as apóiam tenham sumarizado o diagnóstico de seus fatores na política agrária, a verdade é que os dois casos falavam de algo bem mais complexo. As duas tragédias tiveram como protagonistas duas diferentese concorrentes organizações de sem-terra, de um lado, e as polícias esta duais, de outro. 0 u seja, em nossa estrutura federativa e republicana, a política agrária é do âmbito do governo federal, mas os órgãos e agentes de controle da ordem pública, como a polícia, estão basicamente sob gestão dos estados e dos governos estaduais, que têm suas próprias relações de poder, sua própria circunstância e sua própria orientação no que se refere

1. N otará o leitor que trabalho com uma concepção de conjuntura política que se estende aquém e além do período propriamente cronológico do governo deFernando H enrique Cardoso. Do mesmo modo, retrospectivamente, no interior desse período tem início a conjuntura política do governo do presidente Luiz I nácio. A mbosse situam numa conjuntura histórica cujas raízessão anterio- 
res ao golpe de Estado de 1964 e firmam sua possibilidade nosepisódios das "Diretas, já" e do retorno ao regime democrático e civil. à ordem política e social. 0 controle de manifestações que representem risco potencial à ordem pública ainda é atribuição dos estados, o que representa uma sobrevivência do poder das oligarquias regionais, poder que, de vários modos, ainda constitui expressão de uma riqueza que tem na propriedade da terra sua base direta ou indireta de sustentação.

$\mathrm{N}$ uma de suas análises, já na presidência, Fernando $\mathrm{H}$ enrique $\mathrm{C}$ ardoso retorna ao problema dos "dois B rasis", com uma perspectiva mais rica do que aquela proposta por Jacques L ambert (1959). E assinala o complicado cenário político de uma sociedade como esta em que o Brasil moderno se debate com as eficazes sobrevivências do Brasil arcaico. $N$ ão só nos conteúdos das ações dos movimentos sociais referidos à estrutura e aos problemas deste último, como é o caso dos movimentos motivados pela questão agrária (C ardoso, 1994, p. 321). M as também na conduta política das elites regionaise locais, não raro protagonistas da dominação patrimonial e do clientelismo (Idem, pp. 13-22).

Desse modo, o que no âmbito federal é da área da política social, nos estados pode ser da área da ação policial e repressiva. 0 s dois episódios falam menos da questão agrária e falam mais do que é propriamente a questão política da organização do Estado nacional. É cíclica na história republicana do Brasil a tensão entre o poder federal e o poder dos estados, dotados de ampla autonomia no Executivo, no Legislativo e no Judiciário e também nas ações de polícia. N essa disputa de poderes, qualquer episódio de tensão social, como um litígio agrário, pode contribuir para alimentar a tensão latente da organização federativa. É o caso de ações disparatadas, não raro motivadas por disputas de poder, entre a estrutura federativa e a U nião. N o mais das vezes, quem paga a conta desse conflito crônico é o pobre, o desprotegido, não poucas vezes o inocente útil.

No meu modo de ver, em Corumbiara e em Eldorado de Carajás, os objetivos da violência não eram os sem- terra: eram as instituições e o governo. Em particular, a redemocratização do país que ficara na latência do entretanto, em conseqüência da morte inesperada deTancredo $\mathrm{N}$ eves, finalmente ganhou consistência com a eleição do presidente Fernando $\mathrm{H}$ enrique $\mathrm{C}$ ardoso e com a abertura que ele representou na alternância de poder para o advento e a afirmação de partidos de esquerda, como 0 PSD B. Em especial, o muito que essa eleição representava para que outros partidos de esquerda, como o Partido dosTrabal hadores (PT), tivessem de fato reconhecida a legitimidade de sua aspiração de governar o país e de a ele se oferecerem como alternativa política. 
O episódio de Eldorado de C arajás evidenciou a complicada fratura que separa a militância fragmentária que se dá no imediato da sobrevivência e as disputas entre grandes propósitos políticos, sejam os modernos, sejam os arcaicos, nos embates do processo histórico. 0 denuncismo cegou os que se opunham ao governo, no ingênuo desconhecimento da gravidade política do fato, que mais comprometia sua própria sobrevivência de opositores do que o mandato do presidente?

C uriosamente, os dois lados desses conflitos, que combatiam o governo federal em nome dos novos sujeitos ou em nome dos velhos poderes, encontraram- se nesses cenários trágicos, em campos opostos, dispostos a tudo, com o mesmo objetivo político e motivações contrárias: questionar o governo e sua política, especialmente a agrária, mais do que pugnar por uma causa. Porque, de fato, as polícias militares do país inteiro haviam sido, durante a ditadura, desvinculadas da autoridade dos governadores e submetidas ao comando do ministro do Exército, como forças auxiliares da repressão contra as insurgências políticas e populares. Portanto, a ditadura desviara essas polícias de suas funções precípuas, a da manutenção da ordem social, para fazê-las mantenedoras da ordem política autoritária, curiosamente aliada e tutora das oligarquias regionais.

R estabelecido o regime democrático, devolvidas as polícias à autoridade dos governos estaduais, diferentes setores dos governos mantiveramse de vários modos insubmissos, em particular aqueles cuja responsabilidade era e é a da manutenção da ordem ${ }^{3}$. N aA mazônia, ao longo de todo o regime ditatorial, não foram raros os episódios de interferência do poder privado em ações das polícias, seja no trato de questões partidárias, seja no trato da questão fundiária, como sempre foi característico do Bra sil oligárquico. N ão raro as polícias agiram como força de segunda linha de pistoleiros contratados pelas fazendas, sem que isso causasse qualquer escândalo nem provocasse medidas de justa repressão e enquadramento.

o confronto trágico expôs ao governo que contradições históricas, que pareciam resolvidas ou acomodadas, ou superadas porque vencidas pela $\mathrm{H}$ istória, desdobravam-se para fora de seu terreno imediato e próprio. Contradições que se tornavam visíveis no âmbito propriamente político e no âmbito da ameaça à ordem, risco que se configuraria em caso de intervenção federal nos dois estados e suas conseqüências imprevisíveis. O s fatos revelavam, e continuam revelando, que a questão agrária tem hoje mais importância política do que econômica e social. Ao dar vida política às suas vítimas insubmissas e já impacientes, como vem acon-
2. As graveslimitações políticas de compreensão da conjuntura histórica e um conveniente desconhecimento da estrutura federativa do Estado brasileiro persistem na busca de "bodes expiatórios" para as limitaçõese adversidadesjá não apenas de um período governamental, o de Fernando $\mathrm{H}$ enrique $\mathrm{C}$ ardoso, mas, sobretudo, do novo governo do PT. É o que se vê, na convocação de um tribunal de opinião, o Tribunal Internacional dos C rimes do Latifúndio do Pará, em outubro de 2003, com a intenção de pôr no banco dos réus o latifúndio e os governos estadual e federal, julgados por ocorrências e fatos de 1994 a 2002. (C f. F oIha do A mapá, 2003, 7/ 10; também 0 Liberal, 2003, 27/ 10). 0 anúncio da sessão do tribunal foi difundido apenas al guns dias depois de duas das entidadesque o convoca- 
ram, a C omissão Pastoral da Terra (CPT) e o Movimento dos Trabalhadores SemTerra (M ST ), terem divulgado dados, acompanhados de protestos dosrespectivos dirigentes, relativos ao encoIhimento da reforma agrária no governo do presidente Luiz I nácio e relativostambém ao crescimento das tensões sociais no campo e da violência no campo, incluindo um massacre no mesmo estado do Pará. No entanto, essas entidades não incluíram o governo do presidente Luiz Inácio no rol dosacusados. Asreuniões preparatórias do tribunal foram realizadas todas asquintas feiras de outubro, à tarde, na sede daC N BB N orte 2 , em Belém, cf. $F$ olha do A mapá, cit.

\section{A destruição de par-} te dos arquivos da polícia política de São Paulo nessa fase de transição (Souza, 2000, passim), por decisão dos própriospoliciais, constitui um dosváriosepisódios de desordem indicativos de quanto as polícias tomaram suas ações nas próprias mãos. O utro episódio tecendo desde a ditadura, dá vida também àqueles que estão concretamente ameaçados por elas na sua existência anômala e antimoderna. É o caso dos que se nutrem parasitariamente da renda fundiária e do sistema oligárquico que Ihes permite manipular as rédeas do poder local e regional e até mesmo os ritmos da Justiça. N o tabuleiro da política, cada movimento das organizações que falam e agem em nome dos chamados semterra toca menos na questão agrária e toca mais na questão política que a sobrepassa amplamente.

O primeiro governo de Fernando $\mathrm{H}$ enrique $\mathrm{C}$ ardoso havia começado com base na suposição de que o Brasil já não era um país agrícola, que o número de trabalhadores rurais era proporcionalmente pequeno e caminhava para maior redução ainda, seguindo a tendência moderna dos países desenvolvidos. D entro e fora do governo, as demandas feitas em nome dos trabalhadores do campo, não raro com sua escassa participação, apareciam para amplo espectro da inteligentsia brasileira como demandas do Brasil arcaico, em descompasso com o Brasil moderno dos projetos nacionais de desenvolvimento ${ }^{4}$.

Para muitos, a pequena agricultura, ou a chamada agricultura familiar, estava necessariamente presa a técnicas agrícolas atrasadas, de baixa produtividade, e representava uma modalidade de economia destituída de empreendedorismo e de futuro. Algo a não ser estimulado nem apoiado. Estudiosos de esquerda até confundiam, e continuam confundindo, agricultura familiar com agricultura de subsistência. U m setor do governo, representado sobretudo por economistas, pensava desse modo e até havia quem entendesse que mais barata e eficaz do que a reforma agrária seria a distribuição direta dos recursos da reforma aos prováveis beneficiários, como um subsídio que pudesse servir para o início de alguma atividade econômica, de preferência urbana.

N ão obstante essas difusas circunstâncias, o governo defrontou- se com uma enorme pressão por reforma agrária, vinda de setores mobilizados e organizados, especialmente pelas igrejas, em particular pela I greja C atólica, e nela pela C omissão Pastoral daTerra (CPT ), e pelo M ovimento dos Trabalhadores R urais Sem-Terra (M ST ). 0 fato de que essa mobilização não se desse diretamente por meio de canais partidários e assumisse as características de uma arregimentação pré-política centrada em motivos religiosos e morais, aparentemente à margem dos partidos políticos (de fato, porém, alinhada com o PT ), contribuiu para que as ações dos trabaIhadores rurais não fossem reconhecidas por seu impacto na estrutura do 
Estado. C ontribuiu, sobretudo, para que não se reconhecesse que estávamos em face de um governo democrático, capaz de ajustar suas políticas sociais a partir das demandas propriamente sociais, mesmo quando as agências de mediação política, a pretexto de serem voz dos"sem-voz", se negassem a viabilizar no diálogo essa mesma voz.

Q uando senador, Fernando $\mathrm{H}$ enrique $\mathrm{C}$ ardoso já havia chamado a atenção para o fato de que a demanda de reforma agrária não mobilizava no plano político, não chegava a constituir um impasse de natureza política, estava entre as questões que "não se politizaram realmente, não dividem" (C ardoso, 1985a, p. 35). D aí a dificuldade para que ela sensibilizasse e convencesse setores vitais do Parlamento e entrasse na agenda política do Estado brasileiro. A demanda por reforma agrária difundiu-se e avolumou-se à margem do processo político, fora da agenda do Estado, como tema lateral, adjunto, menor e coadjuvante de outras questões políticas. E aí tem, de certo modo, permanecido.

M esmo no interior do PT situou-se como tema marginal, reduzido à condição de mero instrumento de questionamento do então governo, mero recurso eleitoral. D e fato, o PT contribuiu poderosamente para que a reforma agrária ficasse à margem da agenda política do Estado. 0 partido de Lula, e ele próprio, deixou-se convencer pela propaganda interna de que não estava sendo feita uma reforma agrária no país, o que não era verdade; e que a reforma não estava sendo feita porque faltava ao governante vontade política para fazê-la, como declarou o presidente da CPT àTelevisão Espanhola no início de 2001. Ao delegar ao M ST a missão do suposto diálogo, o PT sabia que não haveria diálogo algum. R enunciou por isso à sua própria missão partidária, de interferir nesse assunto de Estado em benefício dos que, de fato, de terra precisavam para trabalhar e viver.

D ifundiu-se a suposição de que bastaria a eleição de um governante do PT para que a reforma desatasse espontaneamente as amarras que a tolhiam. 0 fato de que esse partido, após um ano no governo, continue bloqueado na proposição de uma verdadeira política agrária, ou até mesmo imobilizado e sem condições de dar continuidade à política agrária herdada do governo anterior, é bem indicativo do erro de conteúdo dessa modalidade de ação políticá. É óbvio que, nos longos e muitos anos de sua campanha eleitoral pela presidência, o PT incorporou o tema da reforma agrária no elenco de seus assuntos, mas não 0 assimilou nem tentou compreendê-lo além do imediatismo partidário, como efetiva matéria de governo e de administração política das contradições sociais. revelador desse agir foi o do trágico conflito da praça, em Porto Alegre, em 1990, entre a Brigada M ilitar e o M ST (Lerrer, 1998).

4. Estou me referindo à compreensão geral de orientação do governo, à convergência de concepções orientadoras da política do Estado. A compreensão pessoal de Fernando $\mathrm{H}$ enrique $\mathrm{C}$ ardoso da complexidade da questão agrária e de seu dimensionamento político se materializaria claramente com a nomeação de R aul Jungmann para o M inistério Extraordinário da R eforma A grária. Fernando H enrique a expressou de vários modos nos anos que antecederam sua primeira eleição paraa presidência (C ardoso, 1985 a, passim; 1985b, passim).

5. 0 professor Ariovaldo U mbelino de O Iiveira, da equipe de Plínio deA rrudaSampaio, que preparou a partir de meados de 2003 o Plano N acional de R eformaA grária do governo do presidente Luiz I nácio, declarou, em entrevista de janeiro de 2004: “[...] o governo [...] demo- 
rou um pouco para desencadear o processo de elaboração do Plano $\mathrm{N}$ acional de $\mathrm{R}$ eforma Agrária (PN R A). Só em meados de maio ejunho, com o aumento dosprocessosde luta dosmovimentossociais, o ministério cuidou de preparar o PN R A.Isso mostra que, na realidade, Lula foi eleito sem um plano de fato para o campo. Ao mesmo tempo, há um clima de frustração no fim do ano, em função do baixíssimo índice de assentamentos que 0 governo conseguiu fa zer em 2003. Então, o quadro não énada animador. [...] Ao analisar as metas do PN R A, vemosque elas não são muito diferentes daquilo que o último governo fez. Inclusive, são menores do que o próprio PT játeve naseleições de 1989 e 1994. São metas que considero extremamente tímidas tendo em vista que não alterarão de forma significativa 0 índice de concentração fundiária do Brasil." (O liveira, 2004).
A sorientações pré- políticas que demarcam essa peculiar compreensão da luta pela terra e que respondem pelas objeções que esses grupos tentaram levantar ao programa agrário do governo anterior estão presentes em toscos diagnósticos e não menos toscas e fundamentalistas justificativas de ação política. U m assessor do novo presidente da R epública, que é também assessor do M ST, justifica a ocupação de terras por essa organização com base neste argumento: " $O$ fluxo de diálogo entre o M ST e o governo sempre foi excelente", observou. " 0 s dois estão interessados na mesma questão, um desafio histórico: realiz ar nesse país a segunda reforma agrária, porque a primeira foi a das capitanias hereditárias, só valeu para um lado e agora a gente precisa resolver essa questão" (K attah, 2003, grifo meu).

Se o governo brasileiro tivesse de definir sua política agrária e o M ST tivesse de justificar sua existência por concepções como essa, estariam ambos no beco sem saída de se verem como agentes de uma história que flui do presente para o passado, uma história impossível, a história de uma vendeta de classe e não propriamente a H istória como obra de todos, a realização da H istória possível. E obra mediatizada por nossas contradições sociais e pela práxis, pelo agir histórico, pela qual essas contradições podem ser superadas. Entender que a divisão do território pelo governo português para fins administrativos e a distribuição das capitanias hereditárias aos seus donatários para esse fim tenha sido um ato de reforma agrária é uma simplificação patética.

É preocupante que decisões políticas sobre a questão fundiária possam estar sendo tomadas com base nessa compreensão dos fatos históricos. As capitanias nada tiveram a ver com a formação do latifúndio brasileiro, uma vez que sua função foi a de instituir um sistema de administração do território conquistado em nome da coroa portuguesa, o que incluía obviamente a distribuição da terra. A função das capitanias foi a de produzir renda para a coroa e isso dependia de trabalho, fosse qual fosse a extensão de terra. 0 regime fundiário implantado no B rasil, na época das capitanias, foi o regime de sesmarias, com base na lei com que o rei $D$ om Fernando I, o Formoso, o instituiu em Portugal mais de um século antes da descoberta, em 26 de junho de 1375 (M EAF, 1983, pp. 355-356).

Esse regime constituiu em Portugal, de certo modo, uma medida de reforma agrária. A ssegurava o senhorio do rei sobre o território do reino, o que Ihe dava o direito, constantemente exercido, de redistribuir as terras devolutas, abandonadas ou incultas, o que foi comum no Brasil principalmente nos séculos X VI eX VII . Foi suspenso antes da Independência, por 
R esolução de Consulta da M esa do D esembargo do Paço de 17 de julho de 1822, assinada por José Bonifácio de Andrada e Silva (I dem, pp. 356357). 0 latifúndio brasileiro não nasceu nem da lei de sesmarias nem, obviamente, das capitanias hereditárias. $\mathrm{N}$ asceu do regime de escravidão e da interdição do acesso livre à terra por parte de quem não fosse puro de sangue, branco, e puro de fé, católico. Se não fossem a escravidão e as interdições estamentais da sociedade da época, o regime sesmarial teria criado um Brasil bem diverso deste que herdamos e conhecemos.

O latifúndio se consolidou e se expandiu com a Lei de Terras de 1850, pela qual o Estado brasileiro abdicou do senhorio sobre as terras do país e instituiu a propriedade fundiária privada e plena. C omo resultado, os trabalhadores livres que viessem a substituir os escravos, como se previa, foram privados da alternativa de ocupar livremente a terra livre, não tendo outra alternativa que não fosse a do trabal ho nas grandes fazendas. Esse foi e tem sido um fator de dificuldades para a realização da reforma agrá ria. A questão fundiária brasileira tem origem fundamentalmente nas relações escravistas de trabalho e, já na vigência do trabal ho livre, nas providências para assegurar que a propriedade da terra fosse um meio de coerção da mão-de-obra num mercado de trabalho deliberadamente imperfeito.

M esmo com aquela distorcida visão dos fatos históricos, que apontei acima, fatos sobre os quais atuam, os quadros do PT que têm algum entendimento do que possa ser uma reforma agrária estão, na verdade, no MST e na CPT, e não propriamente nos outros setores do partido. U ma "divisão do trabalho político" que não contribuirá facilmente para o estabelecimento de uma política agrária propriamente petista. B oa prova disso é que após um ano de governo, o partido ainda não tem um programa de reforma agrária em execução, tendo de fato paralisado a reforma agrá ria herdada do governo $\mathrm{C}$ ardoso.

É significativo que o processo de incorporação de organizações extrapartidárias no movimento político, durante a ditadura, tenha al cançado as igrejas, particularmente a I greja $\mathrm{C}$ atólica. D ois fatores, ao menos, contribuíram para que isso ocorresse. De um lado, o regime de exceção que tolhia os partidos no patrocínio de temas relativos a reformas políticas estruturais. De outro lado, os partidos políticos no Brasil vinham e vem perdendo terreno na insuficiência de sua representatividade: novos sujeitos chegaram à cena política e não foram absorvidos na estrutura partidá ria, nem mesmo na decadente prática do populismo. A brigada numa estrutura de I greja, e por ela apoiada moral e materialmente, a demanda de 
reforma agrária cresceu não só fora do âmbito político, mas também fora de sua verdadeira expressão numérica e de sua verdadeira relevância social. C riou-se uma espécie de misticismo agro-reformista, como se o país fosse simplesmente um país agrário, no qual se move até hoje a luta pela reforma agrária. Esse é um fato que dificulta a tradução de sua linguagem e sua ideologia místicas e fundamentalistas, por mais conteúdos justos que tenham, e tem, em projeto político e em ações pautadas pela lógica própria da política. As dificuldades que o governo do PT vem tendo nessa área, no primeiro ano de seu mandato, são bem indicativas do beco sem saída que representa esse misticismo intraduzível na linguagem e na lógica da política, dos partidos e do Estado.

\section{A gênese conservadora dos dilemas políticos da reforma agrária}

Se reconstituirmos esse processo que se deu fora dos quadros partidáriosadmitidos no cenário político brasileiro, poderemos sintetizá lo pelos temas aglutinadores que lhe deram origem e desenvolvimento. É o que pode nos ajudar a compreender al gumas idiossincrasias da questão agrária entre nós e as referências estruturais que fazem com que os que dizem querer a reforma agrária ao mesmo tempo ajam no sentido de questionála e repudiá-la.

A idéia da reforma agrária nasce e permanece no B rasil como bandeira socialmenteconservadora e politicamenteprogressista, o que dá bem a medida da enorme confusão que acerca pela profunda contradição que a limita. A sesquerdas no país, especialmente o PT no período recente e nela as facções representadas pelo M ST e pela C PT, limitam-se às supostas virtudes políticas da reforma, nas estreitezas de sua ótica de classe média reformista dilacerada pelo descompasso entre a retórica e a prática. M as não têm demonstrado a menor compreensão política do fato de que são agentes de um projeto socialmente conservador que, aliás, nem poderia ser outro. É o que faz do discurso do M ST e daC PT um discurso só aparentemente revolucionário. 0 mesmo se constata em relação às agências que lhes são correlatas e coadjuvantes 0 que inclui afala passiva dosacadêmicosque na universidade desempenham a função menor de acólitos, em vez de desempenharem a função social e própria de construtores do pensamento social crítico que tenha na questão agrária um de seus eixos de referência.

A bipolaridade histórica da reforma responde pelas incertezas que a cercam, pelas vacilações de seus executores e, não surpreendentemente, 
pela sua óbvia, ainda que relutante, aceitação pelas elites. A o contrário do que pensam os economistas do momento, a reforma é politicamente desenvolvimentista. A o contrário do que pensam os revolucionários da ocasião, a reforma é socialmente conservadora.

É justamente o que pede que se retome neste ensaio os elementos dessa contradição e as três matrizes de referência nas ações pela solução da questão agrária antes do golpe de 1964: as Ligas C amponesas, o Partido C omunista e a I greja $\mathrm{C}$ atólica (na verdade quatro, se tomarmos como referência a ação do próprio governo G oulart), que adaptadas e modifica das continuam sendo eixos de concepções pré-políticas da questão. De fato, o Estado brasileiro hoje dialoga, com o que delas resta, o difícil diá logo da reforma em seus termos inviáveis.

O pensamento e a ação da I greja C atólica constituem uma dessas matrizes, cuja maior importância política seria demonstrada pelos acontecimentos posteriores ao golpe de Estado de 1964. Antes do golpe, a I greja, hoje protagonista da luta pela reforma agrária, havia se interessado pela questão fundiária em duas ocasiões. A primeira em 1950 quando, por temer o proselitismo comunista nas bases católicas dos desenraizados do campo, o bispo de C ampanha, D om Inocêncio Engelke, de $M$ inas $G$ erais, lançou uma carta pastoral de natureza nitidamente conservadora e anticomunista. Foi preparada numa reunião de que participaram sessenta padres de paróquias rurais, 250 proprietários de terra, 270 professores rurais e várias pessoas de ordens religiosas que trabal havam em escolas secundárias (CN BB, 1976, passim; De Kadt, 1970, p. 72). $\mathrm{N}$ ela proclamava a inevitabilidade da reforma agrária como medida preventiva em relação ao risco de um avanço comunista entre trabalha dores rurais e mais ainda entre os urbanos de origem rural. Leve-se em conta que M inas era o estado que mais enviava migrantes para São Paulo nessa época, o que privava a grande propriedade da mão-de-obra barata da qual dependia.

U ma segunda medida de mesmo teor foi a ação do bispo D om Eugênio deA raújo Sales, de N atal, no R io G rande do N orte, em 1959, através do Serviço de Assistência R ural, com a antecipação da iniciativa da criação de sindicatos de trabalhadores rurais como recurso para bloquear 0 avanço das Ligas $\mathrm{C}$ amponesas e mesmo 0 avanço da sensibilização dos tra balhadores pelos comunistas ${ }^{6}$. $\mathrm{R}$ io $\mathrm{G}$ rande do $\mathrm{N}$ orte foi o único estado do $N$ ordeste em que as Ligas não conseguiram atuar, em conseqüência dessa medida.
6. Sobre as posições do futuro cardeal a respeito do tema, cf. Sales (1960). Sobre a forte motivação anticomunista da CNBB no apoio a D om Eugênio Sales, na questão da sindicalização rural, cf. Botas(1983, pp. 39 e ss). 
7. A esse respeito, o padre Alberto Antoniazzi esclarece:"A I greja tinha apoiado a política'desenvolvimentista' dos anos 50, tinha mantido o apoio às'reformas de base' no início dosanos60, até a declaração da C omissão Central de abril de 1963, por ocasião da divulgação da ' $\mathrm{Pa}$ cem in Terris'. N esta altura, porém, as divisões no seio do episcopado se manifestam. O cardeal Dom Jaime de BarrosC âmara [que era o arcebispo do $\mathrm{R}$ io de Janeiro, JSM ] se demite da presidência da C N BB, Dom H élder pede para deixar o lugar de auxiliar do $\mathrm{R}$ io de Janeiro e é transferido em março de 1964 para São Luís do M aranhão e, logo depois, para O linda e R ecife (posse em 11.4.1964). 0 'golpe' de 31 de março de 1964 leva a uma 'reunião extraordinária dos M etropolitas' em 27-29 de maio, da qual sai uma declaração que aceita a intenção da 'R evolução' de livrar o País do comunismo e agradece aosmilitares, mas faz ressalvas e 0 voto de que a reconstrução do País siga a Doutrina Social da
D iferentes setores da I greja empenharam- se na mobilização dos traba Ihadores rurais em programas de conscientização que indicam uma competente percepção da reforma conservadora como instrumento de desenvolvimento social. M as nos lembremos de que a I greja dividiu-se quanto ao apoio às reformas de base, a mais problemática das quais era a modesta reforma agrária proposta por Goulart, que constituía um componente de expansão do populismo trabalhista. Embora as orientações pastorais da comissão central da C onferência N acional dos Bispos do Brasil (C N BB), cujo secretário era D om H élder C âmara, fossem favoráveis às reformas, essa opção provocou considerável inquietação no episcopado (Schmitter, 1971, pp. 216, 444-445)7. o que se viu foi, no geral, os bispos omissos ou em apoio franco ao golpe militar de 1964.Temiam não só a subversão no direito de propriedade, mas também a ascensão política dos comunistas e das Ligas. $\mathrm{N}$ ão deixa de ser eloqüente e esclarecedora a famosa afirmação de D om H élder, dias após o golpe de Estado, com o país varrido por perseguições políticas e prisões de trabalhadores e militantes da causa da reforma agrária: " $\mathrm{N}$ ão podemos abandonar bandei ras boas porque estão em mãos erradas." C ontra as "mãos erradas", a I greja optava pela bandei ra boa da reforma agrária, reconhecimento da função conservadora desse instrumento de reforma social.A cima de tudo, essa afirmação expressa o quanto as esquerdas tiveram dificuldade para compreender na época a situação social e política, numa polarização ideológica que alijava a possi bilidade de um grande pacto político pelas reformas de base.

U m aspecto fundamental da disputa na mobilização dos trabalhadores rurais no Brasil nos últimos cinqüenta anos tem sido o de que as linhas ideológicas de referência são dos partidos e dos grupos de mobilização política e não necessariamente dos trabalhadores. A práxis e a consciência social de nossos trabalhadores, sobretudo rurais, têm estado insuficientemente representadas nas ideologias partidárias, em geral adaptações locais de orientações ideológicas desenvolvidas em outras sociedades e em outras situações. Já para não falar no fato insólito de que, ao longo da história contemporânea do Brasil, os trabalhadores rurais têm sido ignorados como sujeitos de idéias, ideais e vontade histórica. 0 s trabal hadores rurais entram na cena histórica brasileira pelo avesso e lentamente. M esmo num partido social e popular, como o Partido dosTrabalhadores, os trabalhadores rurais agregam-se como um corpo estranho. É o que nos mostra o fato de que tanto o M ST como a CPT funcionem como uma espécie de incompreendido departamento rural partidário, embora com ideologia e 
comando próprios escassamente inspirados na práxis e nas tradições das populações pobres do campo.

D esse modo, no último meio século, os trabalhadores rurais têm sido mobilizados tanto por organizações de esquerda como de direita, sem que essa polarização Ihes diga algo substantivo sobre reforma agrária "de esquerda" e reforma agrária "de direita" , um falso dilema. N os anos cinqüenta e início dos anos sessenta, a alma e a lealdade camponesas foram disputadas tanto por D eus como pelo diabo. $\mathrm{N}$ a peleja empenharam-se tanto a I greja $\mathrm{C}$ atólica, numa clara linha anticomunista de conduta, como se vê nas duas manifestações indicadas, como o Partido Comunista, e também as Ligas $\mathrm{C}$ amponesas?.

$G$ rosso modo, as três organizações lutavam entre si por uma clientela e não primariamente por uma causa que fosse dos próprios trabalhadores rurais. Tratava-se, e ainda se trata, de uma grande disputa entre a modernidade difícil e a tradicionalidade ameaçada. 0 que estava em jogo, e preocupava tanto a esquerda como a direita, era o já inevitável advento político das populações rurais e seu lugar nesse embate histórico. D ecorria ele do esgotamento do modelo de relações de trabalho forjado na crise da escravidão, no século XIX, que substituíra o trabalho escravo por formas nãocapitalistas de produção. U m modelo que segurou ainda por um século inteiro a modernização das relações de produção no campo e assegurou, ao mesmo tempo, uma forma peculiar de acumulação primitiva e uma fonte de lucro extraordinário nos empreendimentosurbanos que foi fundamental em nosso processo de industrialização. Este país não deu um salto para o mundo moderno: fluiu e flui lentamente em sua direção pelos meandros de arcaísmos e do tradicionalismo, de que o moderno se nutre.

D e modo algum, essa disputa tinha a ver primariamente com ideais de justiça social. A justiça social seria uma decorrência da reforma, deixando aos mediadores o sobrelucro dos trabal hadores organizados e ideologicamente alinhados com os grupos de mediação interpostos entre a necessidade social e a meta política da reforma agrária. C uriosamente, os agentes mediadores da demanda por reforma agrária, na esquerda e na direita, vinham (e continuam vindo) de diferentes orientações ideológicas de elite e de histórico menosprezo pela competência política e transformadora dos trabalhadores da terra. D aí a estratégia da tutela.

0 mea aulpa, tão próprio da atual situação brasileira, em relação a índios, escravos e camponeses, constitui um traço característico de trajetórias e biografias próprias de um quadro de realocação das elites na estru-
Igreja" (A ntoniazzi, s.d.).

8. Em relação às disputas nas esquerdas entre uma solução agrária e uma solução trabalhista dos problemas do campo, cf. G naccarini (1980) e M oura (1988). 
tura social, uma redefinição de posições sociais e de perspectivas. São mudanças que impõem, justamente, a muitos dos por elas alcançados, a necessidade moral e política do acerto de contas com a história social da respectiva classe, sem o que a mudança se tornaria subjetivamente insuportável. D aí a importância dramática que essas correções biográficas assumem e a necessidade interior de dar visibilidade ao drama como se fosse drama de todos e não só de alguns. N ão se deve, porém, subestimar a importância sociológica de criar técnicas sociais de ajustamento e atualização próprias desses esforços de arrependimento coletivo. Elas nos falam de uma sociedade disposta a reconhecer o lento desaparecimento da velha ordem e os desafios da sociedade que se propõe nos fatos novos, nos conflitos, nas tensões e até mesmo nos desapontamentos. Por mais transitório que tudo isso seja, como de fato é, estamos diante de verdadeiros documentos sobre as transformações so ciais que nos ajudam a compreen dêlas e dar-Ihes 0 apropriado rumo, compatível com os anseios de emancipação do homem numa sociedade com tão marcados bloqueios e limitações a que a emancipação ocorra.

A própria raiz de classe social dos que em nome dos trabalhadores rurais falavam, com uma ou outra exceção, direta ou indiretamente, estava nas oligarquias latifundistas, como era o caso de Francisco Julião. Algo que já acontecera na abolição da escravatura, no $\mathrm{N}$ ordeste, com gente da envergadura de Joaquim $\mathrm{N}$ abuco e, no Sudeste, Antônio da Silva Prado. $\mathrm{N}$ ão se tratava, pois, apenas, propriamente da emergência política dos trabal hadores rurais, mas da diversificação política das elites num cenário de crise social, política e econômica. Enfraquecidas nessa diversificação, buscaram aliados nos trabal hadores e impuseram tutelas políticas em relação às populações que, de outro modo, também estavam sendo alcançadas pela mesma crise. Isso ocorreu em boa parte porque as elites fracassaram na proposição e na sanção de um pacto entre elas, como haviam feito na abolição da escravatura, que viabilizasse uma reforma agrária que não poderia deixar de ser feita e seria inviável sem a participação de novos protagonistas políticos, como os comunistas e os sindicatos.

A crise agrária não desorganizou apenas as relações de trabalho e, portanto, a vida dos trabal hadores. D esorganizou, também, as relações de poder e a vida das elites tradicionais. A resposta do golpe militar amaciou a queda, mas cobrou dessas elites o tributo de um Estatuto daTerra que não desejavam e do reconhecimento da legitimidade da reforma agrária que tampouco queriam. 0 governo militar, porém, agradou-as e dividiu-as, 
realimentando-as com a política adotada na A mazônia legal, pela qual os empresários recebiam o prêmio dos incentivos fiscais, o capital de seus empreendimentos como doação, sujeitos porém a pagar aos titulares de terra o tributo parasitário da renda fundiária. Algo que já havia sido feito no N ordeste, com a criação da Superintendência do Desenvolvimento do N ordeste (Sudene). U m reforço modernizador e significativo no instituto da propriedade num quadro de preservação de interesses de classe. U ma outra via de modernização do país, mediante a conciliação do capital com a renda da terra, diversa da modernização que as esquerdas laicas propunham, que implicava um questionamento da renda da terra e até a supressão do lugar social e político dos proprietários de terra.

U m erro certamente: uma esquerda dividida e fraca em face de uma elite fundiária coesa e politicamente forte. U ma esquerda minada em seus propósitos reformistas porque dividida entre a relutância pela reforma agrá ria e a opção preferencial pela reforma trabalhista, obrigada ainda a disputar a bandeira da reforma agrária com o conservadorismo católico, que foi 0 que de fato vingou e baliza a luta pela reforma agrária até hoje. N ossas esquerdas têm grande dificuldade para reconhecer e aceitar a importância socialmente tranfformadora da tradição conservadora e o quanto ela pode pesar e pesa nas reformas sociais no mundo contemporâneo quando se torna cultura de referência das necessidades radicais, aquelas que pedem transformações estruturais ${ }^{9}$. Essa é uma virtude potencial da situação conflitiva em que vivemos e que, infelizmente, a própria I greja não consegue compreender em todas as suas implicações. $\mathrm{N}$ ão é preciso que os grupos que atuam em nome dessa tradição se finjam ou se mascarem de marxistas para que lutem por justiça social e logrem importantes reformas sociais na sociedade capitalista.

É isso que de outro modo continua em jogo até hoje. N ão estávamos nem estamos de fato, em primeiro lugar, em face de uma luta pela reforma agrária nem de uma luta dos trabalhadores rurais, e sim de uma luta pela afirmação do poder político das organizações de mediação da representação política dos trabalhadores rurais, uma expressão da expansão e da diversificação das elites. Trata-se de uma luta pelo poder e não primariamente de uma luta por transformações sociais. N ão é, portanto, estranho que no ano da graça de 2003, segundo informação da 0 uvidoriaA grária do M inistério do D esenvolvimento A grário, já fossem 75 as organizações de mediação política que disputavam o controle político da vontade dos trabalhadores rurais e de suas demandas, todas falando em nome de um
9.0 s vários trabal hos deThompson (2002), um marxista, tratam magistralmente desse tema. Sobre as necessidades radicais, cf. H eller (1978). 
abstrato e diversificado trabalhador sem-terra e todas patrocinando ocupações de terra.

A questão agrária, que ganhara visi bilidade política intensa na ação das Ligas $\mathrm{C}$ amponesas, particularmente no $\mathrm{N}$ ordeste canavieiro, antes de abril de 1964, reaparece após o golpe de Estado com a rápida disseminação da violência no campo, na A mazônia e no C entro- oeste, a partir da criação da Superintendência do Desenvolvimento da Amazônia (Sudam) e da política de ocupação daA mazônia. M as, o Estatuto daTerra fora pensado principalmente tendo em vista o $\mathrm{N}$ ordeste e não as frentes de expansão no Sul, no Centro-oeste e no N orte onde, desde os anos cinqüenta, vinham ocorrendo revoltas camponesas locais, que até mesmo envolveram as Forças A rmadas na repressão, como ocorreu em Dianópolis, no norte de Goiás.

Grandes empresas beneficiadas pelos incentivos fiscais lançaram-se sobre o território da A mazônia legal, o que incluía o C entro- oeste e a PréA mazônia maranhense. Posseiros antigos começaram a ser expulsos com violência, populações indígenas foram dizimadas e tiveram seusterritórios ocupados. A I greja na A mazônia viu-se diante de uma ação de ocupação territorial que afetava profundamente sua própria existência, substituindo pessoas por gado, mas que afetava so bretudo a essência de seus val orese de suas orientações morais e religiosas. A quele era o limite moral além do qual já não seria possível insistir na defesa da propriedade privada da terra, direito em nome do qual a condição humana estava sendo posta em questão na ocupação territorial acelerada, subsidiada e genocida.

$\mathrm{R}$ alph Della $\mathrm{C}$ ava, um dos melhores conhecedores da história contemporânea da I greja $C$ atólica no B rasil e das orientações do Vaticano em relação às igrejas particulares, numa proposta de periodização histórica, chama a atenção para um fato a ser ainda esclarecido, segundo ele: a manifestação da Pontifícia Comissão de Justiça e Paz, em 1970, e mais tarde do próprio Papa Paulo VI, denunciando a tortura no Brasil (D ella Cava, 1986, p. 17). Esse cenário favorável a um amplo compromisso da Igreja com a questão dos direitos humanos, no meu modo de ver, abriu espaço para o florescimento das pastorais sociais fora do eixo político convencional, que caracterizara a esquerda católica nos tempos de Goulart, nos limites, porém, do consentido por $\mathrm{R}$ oma.

Durante quase dez anos, portanto, a ditadura militar pôs e dispôs a respeito daquela ocupação territorial sem que as igrejas locais reagissem em conjunto. Fundamental exceção foi a carta pastoral de Dom Pedro 
C asal dáliga, de 1971, em que o desenraizamento violento das populações indígenas e camponesas do norte do $M$ ato Grosso foi denunciado com indiscutível clareza e inegável coragem (C asaldáliga, 1971). Ao que se acrescenta, em 1973, a criação do C onselho Indigenista M issionário (C imi), pela CN BB, que passaria a ter um papel de grande relevo na denúncia das invasões de terras indígenas e no combate à violência de que os índios eram vítimas, um verdadeiro e indiscutível extermínio.

Q uando, finalmente, a C N BB patrocinou um encontro que redundaria na criação da C PT, em 1975, fê-lo no capítulo dos direitos humanos, como já ocorrera na criação do C imi. D e fato, o modelo de desenvolvimento econômico representado pela política de incentivos fiscais não era ainda questionado. A penas seus efeitos mais drásticos. 0 slongos anos que se passaram entre o golpe de Estado e a tomada de medidas de contestação dessa política deram tempo para que o modelo se firmasse e os grandes empreendimentos apoiados nos incentivos fiscais se enraizassem na região amazônica. D e fato não havia ali, a rigor, quem se opusesse à voracidade predatória das grandes empresas senão as igrejas. Essa demora de cerca de dez anos na ação prática organizada e sistemática - e de quase quinze anos para que fosse adotado um ponto de vista articulado sobre a diversidade da violência no campo, o que aconteceu com o documento I greja e problemas da terra (CN BB, 1980) - foi suficiente para firmar a orientação do Estado brasileiro de favorecer e patrocinar uma política de associação do capital com a propriedade da terra e vincular lucro e renda territorial como meio de assegurar que ao lucro do capital se agregasse 0 lucro extraordinário da renda da terra.

Essa opção consagrou uma característica histórica da reprodução ampliada do capital neste país e fortaleceu poderosamente os obstáculos à reforma agrária entre nós. As desapropriações não só se tornam assim antieconômicas, como também as indenizações acabam sendo absorvidas pela lógica do sobrelucro do capital, representado pela renda fundiária. A insistência na desapropriação como único meio de constituir o fundo de terras para a reforma agrária, que é a posição do M ST e da C PT, reforça essa irracionalidade que é do maior interesse justamente do latifúndio. É uma simplificação supor que o mecanismo da desapropriação estatiza a propriedade da terra e constitui, por isso, um passo na direção de um suposto socialismo de Estado. A té porque o governo, em seguida, repassa essa terra ao assentado, reconvertendo- a legalmente em propriedade privada, o que tem reiniciado o ciclo da concentração fundiária nos próprios assentamentos. 
10. A opção da Igreja, naquela ocasião, não é estranha, porém, à luz do fato de que entre acampados já havia tanto a experiência de comprade possescomo a disposição de comprar terra ou de pagar a terra com os meios obtidos no trabalho agrícola (M éliga ejanson, 1982, pp. 19 e 21). 0 acampamento foi organizado em dezembro de 1979, à beira da estrada de R ondaA Ita. Para uma útil resenha dos fatos históricos relativosao conflito que culmina no acampamento de EncruzilhadaN a talino, tido como o primeiro episódio de nas cimento do M ST, cf. M aestri (1999). Sua importância na futura formação do MST é destacada também por Stédile (2002, p. 81).
A posição dessas entidades é estranha e contraditória em face da iniciativa pioneira da I greja de funcionar como um banco da terra na emergência da grave situação dos acampados da Encruzilhada $\mathrm{N}$ atalino, em R onda Alta, no $\mathrm{R}$ io Grande do Sul, que haviam se recusado ao deslocamento para Lucas do R io Verde, no $\mathrm{M}$ ato $\mathrm{Grosso}{ }^{10}$. U m mecanismo em que, ao invés do preço da terra ser determinado em última instância pelo vendedor, pelo desapropriado, especialmente através da interferência do Judiciário, poderia ser determinado pelo comprador, que teria o poder de comprar o que quisesse, pelo menor preço, se dispusesse de crédito imobiliário. São necessárias intervenções no mercado de terras para deprimir a renda da terra e ampliar 0 alcance do mecanismo da desapropriação.

$N$ esse sentido, a estratégia de impugnar qual quer outra forma de acesso à terra, que não seja a da desapropriação, não amplia o campo das possibilidades da reforma agrária nem representa proposta conseqüente de reforma agrária. Esse é um impasse para o qual nenhum dos grupos, com facilidade de fazer pressões, têm uma alternativa viável e conseqüente. $\mathrm{N}$ em o novo governo a tem.

Se entendermos a reforma agrária, num país como o Brasil, como um processo de distribuição e redistribuição de terras, e de correção ádica da estrutura fundiária concentracionista, centrado num projeto político e social de fortalecimento e expansão da agricultura familiar, ela ampliará sua viabilidade se diversificar e multiplicar os mecanismos de acesso à terra e o fizer num esquema técnico que deprima os ônus sociais da renda territorial. Isso já não será necessário nem possível se a reforma agrária for concebida como um programa de punição e acerto político de contas numa ótica diminuta e provavel mente obsoleta e desatualizada da luta de classes.

Do ponto de vista político, só tem sentido corrigir as iniqüidades em vez de vingá-las. C omo é politicamente essencial punir com a lei as injustiças praticadas por meio de ações ilegais, de que são invariavelmente vítimas famílias desprovidas de meios e até mesmo do mínimo respeito a que têm direito. $M$ as isso não fará reforma agrária nem qual quer outra reforma social. No tipo de economia que temose na situação econômica que enfrentamos é fundamental reconhecer a privilegiada condição de um país que pode fortalecer e alargar as possibilidades da agricultura familiar. E, com isso, salvar e reaproveitar o capital social representado pela competência agronômica de populações que não raro têm sido tratadas com prejudicial desprezo, como se fossem ignorantes e até mesmo idiotas culturais. Preconceito que é próprio, aliás, de um país que confunde analfabetismo e 
baixa escolaridade com ignorância. Privilegiada condição também porque essa opção não anula nem tem que impugnar a convivência com o agronegócio e a grande lavoura comercial, essenciais ao processo de acumulação de capital para que o país se desenvolva numa escala que não pode ser a dos pequenos países pobres e das economias limitadas, como a cubana e a nicaragüense do sandinismo. N ossos desafios são outros e são outras as nossas possibilidades.

\section{0 retorno social e político do tema da reforma agrária}

O que preocupava a CN BB com a questão dos direitos humanos no campo, ao fim de dez anos de ditadura, era justamente a extensa e impune violação desses direitos pelo Estado e por grupos privados. Propunha-se a combatê-la de forma organizada em nome desses direitos. Era medida sem dúvida de grande urgência. $\mathrm{N}$ ão havia preocupação prioritária com a questão fundiária nem compreensão das tensões nessa perspectiva. D esde 0 golpe de Estado, a I greja não havia revisto sua posição política sobre o direito de propriedade e a reforma. Só poucos anos depois de sua fundação, a CPT começará a falar propriamente em reforma agrária como possível solução para o problema do campo, até que esse tema se torne 0 seu tema central e praticamente exclusivo anos depois.

M as falará a partir da experiência dos conflitos fundiários cuja dimensão, não raro trágica, foi o seu desafio de origem. Falará, portanto, numa reforma agrária diversa da que motivara as esquerdas antes do golpe de 1964. D e um lado, porque sua referência será a reforma agrária demarcada pelo Estatuto daTerra da ditadura, um programa "de direita" , isto é, diverso das propostas do período Goulart. E nem havia outra alternativa viável. D e outro lado, porque sua referência será nesse início a demanda efetiva de direitos sobre a terra por parte de trabalhadores rurais ameaçados de expulsão e dispostos a resistir. Porém, conservadores quanto a suas motivações. Já não eram os insubmissos moradores dos canaviais do $\mathrm{N}$ ordeste os que agora protagonizavam a demanda de terra para trabal har. Eram outros os sujeitos, as circunstâncias, as necessi dades e as aspirações.

Compreende-se. $\mathrm{N}$ os primeiros tempos do golpe, a repressão política brutal e a aprovação do Estatuto, que se manteve por longo tempo com ela conexa, a cessação da atividade dos grupos que antes haviam pelejado pela reforma agrária, recobriram de silêncio o que havia sido a mais inquietante proposta de reforma de base. As esquerdas recolhidas pareciam 
entender que o golpe, a repressão e a reforma agrária da ditadura eram clara indicação de que esse tema já não tinha de fato nenhum conteúdo politicamente transformador e, de certo modo, fora um engano que comprometera avanços em outras áreas da política brasileira. Só aos poucos o tema da reforma agrária voltou ao elenco dos assuntos da militância política, recoberto da ironia, não raro tola, de setores elitistas e desinformados da intelectualidade. A redescoberta da questão agrária, ainda que tardia, a partir de uma matriz nova de sua compreensão e definição, deveu-se muito ao trabalho da Igreja, apesar das óbvias e compreensíveis relutâncias de membros da hierarquia.

No meu modo de ver, foi fundamental que essa redescoberta fosse feita através de um setor da sociedade ainda não contaminado pelo xarope das frases feitas de um leninismo de manual. Em especial um setor não contaminado pelo pressuposto da centralidade ideológica e dos interesses da classe operária fabril no processo político. Portanto, uma redescoberta dos problemas do campo através de um grande esforço de compreensão da questão agrária como tragédia e não mais como déficit histórico e necessidade de modernização econômica. D esse modo, a questão agrária não reaparecia como tema tópico, como havia acontecido nos embates entre os três grandes grupos de referência antes do golpe: as Ligas $\mathrm{C}$ amponesas, o Partido C omunista e a I greja. A questão agrária aparecia como tema vital, como revelação de um sistema econômico profundamente injusto, que tratava populações indígenas e camponesas como seres descartáveis, provavelmente aquém da condição humana.

D e certo modo, a defesa dos direitos fundiários dos posseiros abrigavase sem tensões doutrinárias e de princípios no escrúpulo da Igreja em relação ao direito de propriedade que ela defendia. Algo mais confortável do que assumir a causa de trabal hadores dependentes, como moradores e colonos, das fazendas de cana e de café, o que teria lançado a I greja no miolo da luta de classes. Com uma diferença, que naquele momento ainda não estava clara na consciência dos agentes de pastoral e certamente não 0 estava também na consciência da maioria dos bispos. A defesa dos direitos fundiários dosposseiros, que teve seu momento de maior vigor najá mencionada carta pastoral de D om Pedro C asal dáliga, em 1971, e que se confirmou amplamente na fundação da CPT, em 1975, emergia como defesa do direito de propriedade, particulariz ado, porém, no direito derivado do trabalho.

A questão dos posseiros punha em confronto duas modalidades de acesso à terra, características da história brasilei ra: 0 trabalho, que não sen- 
sibilizava nem sensibiliza governantes e juízes, e o documento de compra, verdadeiro ou com aparência de verdadeiro, que é o que conta para as autoridades judiciárias quando chamadas a decidir quem tem direito a uma terra em disputa. D esse modo, o envolvimento da I greja na questão agrária tornou-se possível com o decantamento do direito de propriedade, nele separando a propriedade que é fruto e condição do trabalho da propriedade que é fruto do próprio direito de propriedade, do poder e não raro da violência.

M inha experiência, de muitos anos, de pesquisador de campo, aí incluída a A mazônia, mostrara-me o quanto essa distinção é clara para aqueles que vivem a ambigüidade da situação de trabalhadores e de proprietários ou possuidores de terra ${ }^{11}$. Solicitado a assessorar a assembléia dos bispos, em 1980, propus, através de um documento de apoio ${ }^{12}$, que essa distinção fosse explicitamente reconhecida e assumida pelo episcopado na preparação e na aprovação do documento I greja e problemas da terra. Com pequenas modificações terminológicas, a legitimidade da luta pela terra como luta pela terra de trabalho foi nesse documento reconhecida pela assembléia dos bispos, em confronto e antagonismo com a terra de exploração, ou terra de negócio (C N BB , 1980), legitimando e ampliando, desse modo, o referencial teórico da ação pastoral da CPT. A penas quatro bispos não se manifestaram a favor do documento num colegiado de quase trezentos.

A luta dos posseiros, abrigada pela I greja no reconhecimento da sua legitimidade em face do direito de propriedade, continha e contém uma contradição criativa no estabelecimento de condições ao exercício desse direito, 0 que se poderia chamar de contradição histórica entre 0 fato e a lei. A ação pastoral que dessa situação decorreu e decorre continha um germe de vocabulário normativo, esboçado na potencial centralidade conceitual da noção de terra de trabalho, de difusa presença na mentalidade e na experiência dos trabalhadores, algo que as pessoas intuíam mas não compreendiam e não compreendem ainda. O u seja, uma necessidade de definição social que decorre de uma alteração de perspectiva ${ }^{13}$. A prática definida a partir dessa idéia-elemento ${ }^{14}$ não emergia e continua não emergindo na consciência dos protagonistas em seus termos próprios, fundamentalmente porque enredados num sistema conceitual postiço e atrasado em relação à sua própria vivência que, por isso, se mantém anômica.

Com mais clareza a partir de então, a CPT e a própria C N BB advoga ram em favor não só dos direitos consuetudinários das populações que tinham um modo próprio de se relacionar com a terra e com o direito à
11. Trato extensamente desse tema em livro recente ( $M$ artins, 2003).

12. A íntegra desse documento foi publicada no mesmo ano com 0 título de "Terra de negócio e terra de trabalho: contribuição para o estudo da questão agrária no Brasil" (M artins, 1980, pp. 4566). A relevância dessa distinção é retomada em B off (1981, pp. 103-104).

13.Valho-me aqui, com liberdade que reconheço ampla, de noções de $Q$ uentin Skinner (2000, pp. 12 e 30) relativas a contexto social e histórico completamente diverso. A tese de Skinner, guardadasasóbvias diferenças de época e de situação, é uma referência de grande utilidade para se compreender o processo de gestação de um novo sujeito político que nasce também sujeito conceitual e núcleo de definição de um vocabulário explicativo novo. Seus desdobramentos podem ser observadosno cenário político modificado pelo advento desse novo sujeito que é um traba- 
Ihador rural que carrega consigo umagrande carga de possibilidade de modificação do sistema de orientação da ação histórica. M as, em nosso caso, em uma situação sociologicamente rica, temos protagonistas politicamente pobres. Com freqüência, os agentes de mediação estão aquém das possibilidadeshistóricas nela contidas, presos em uma trama de referências ideológicas relativas a experiências estranhas à sua própria, a valores do passado eaumaprá tica política autoritária, com severas dificuldades para compreender e realizar a esperança que aí se anuncia.

14. A ssim como se pode identificar idéiaselementos de orientação de um sistema de conhecimento, como nos mostra $\mathrm{N}$ isbet (1969, pp. 15-36) em relação à sociologia, pode-se também identificar idéias- elementos do senso comum de uma época que propiciam referências de compreensão propriamente sociológica de determinada situação social.

15. A Lei no 601 , de 18 terra, em particular a terra como instrumento de trabalho e meio de vida. $\mathrm{N}$ a contraposição entre a lei e o costume, reconheceram a legitimidade do costume, o que al cançava as populações justamente abandonadas pela Lei deTerras, em $1850^{15}$.

M ais claros ficaram, também, a demanda de terra e o sentido dessa demanda nas pressões dos pequenos agricultores do Sul do Brasil, diversa da demanda dos posseiros da extensaA mazônia.Variantes das posições e definiçõespropostas nesse documento, aliás, foram de al gum modo assimiladas nas concepções do direito de propriedade da Constituição de 1988. Em especial no alargamento do perfil sociológico do sujeito desse direito. São basicamente concepções do antigo regime sesmarial, sobreviventes na cultura e na prática dos trabal hadores rurais.T rabal hado res que conseguem perceber com mais clareza do que amplos setores da I greja, do Estado, do meio acadêmico, da totalidade do M ST e do seu partido, e das várias outras organizações de sem-terra, as virtudes sociais do que resta do regime sesmarial na tradição do povo. Em particular, quando o regime sesmarial aparece nas suas potencialidades sociais, reveladas com a supressão da escravidão. U m regime que fora no seu tempo, aliás, como mencionei antes, um programa de reforma agrária em que o direito ao uso da terra decorria do trabalho que a tornasse produtiva. Era a produção que legitimava a posse da terra. U m privilegiamento do trabalho atravessado pela anomalia da interdição do acesso à titularidade da terra aos cativos, aos que efetivamente trabalhavam.

0 recurso à legislação de reforma agrária, no caso dos posseiros, devia-se a uma estratégia também adotada pela C onfederação $\mathrm{N}$ acional dos Trabalhadores naA gricultura (C ontag): a de que a própria ditadura militar havia produzido uma mudança constitucional que possibilitava a desapropriação de terras para reforma agrária e havia produzido um Estatuto daTerra que definia parâmetros para diagnósticos de tensão social, desapropriações a assentamentos. 0 recurso à reforma agrária da ditadura era a única saída legal para combater as expropriações violentas praticadas pelas grandes fazendas contra pequenos agricultores, posseiros sem título de propriedade. 0 Estatuto nesses casos foi invocado diferentes vezes pelos bispos e pelos sindicatos quando tiveram oportunidade de se dirigir ao governo militar para tratar dos problemas do campo. A reforma ainda não era o objetivo, era o meio para assegurar justiça social localizada. $M$ ais tarde, a reforma pela reforma se constituiria na meta essencial dos chamados movimentos sociais, na verdade organizações convertidas em grupos 
de pressão com interesses próprios, para as quais a reforma se tornaria meta e meio político.

A solução da ditadura para os problemas sociais derivados da questão agrária, isto é, o Estatuto daTerra e a legitimação da demanda por reforma agrária, liberou a I greja do temor de reivindicar uma reforma a que se opusera antes do gol pe, basicamente porque supostamente atingia um dos pilares da ordem política e social, que era o direito de propriedade. D iferente do que a reforma se tornaria depois para a própria C PT : um objetivo cerrado, independente das diferentes e contraditórias funções que pudesse cumprir.

Pouco alarde tem feito a Contag de seus próprios feitos e de sua própria luta pelos direitos trabal histase pelos direitos fundiários dos trabal hadores rurais, numa longa e significativa história. Embora sua ação seja, no conjunto das organizações que desses temas tratam, a mais consistente e, certamente, a mais política. Já o grupo mais seculiar e de maior visibilidade é sem dúvida o M ST, originado na C PT, não raro um e outra atuando como face e contraface da mesma causa e da mesma idéia. Sua ação é politicamente mais débil, de menor al cance, embora partidariamente mais agressiva. De fato, é a única articulação política que se norteia por uma ideologia quase precisa, insuficientemente compreendida e interpretada pelos próprios protagonistas. D iferente da Contag, cuja ação tem uma certa dimensão técnica e prática, voltada propriamente para a solução dos problemasque a motivam, sem vínculo com um projeto partidário explícito, dominante e prioritário, disposta ao diálogo político, isto é, disposta a um agir político compartilhado.

É significativo que o M ST tenha no althusserianismo estruturalista e no guevarismo foquista suas principais referências teóricas e ideológicas. E também sua principal limitação e sua mais grave contradição, embora inevitáveis na ponte de que se vale na relação com os setores católicos subsistentes da, não obstante, rica, criativa e iluminadora onda de concepções daTeologia da Libertação. N o estruturalismo, a explicação materialista causal. No guevarismo foquista, a celebração do martírio e do profetismo voluntarista que tempera e "corrige" o mecanicismo antihistórico próprio da análise althusseriana, extrapolando o que é propriamente político.

O M ST é uma organização política peculiar, acossada seja pela indiferença de diversos setores da sociedade em relação à luta pela reforma agrária, seja pelo burocratismo do Estado, seja pelo abismo que via de de setembro de 1850, conhecida como Lei deTerras, dispôs sobre as terras devolutas e a revalidação das terras possuídas por título de sesmaria, além da legitimação de posses mansas e pacíficas mesmo no interior das sesmarias, em todos os casos desde que fossem cultivadas ou tivessem princípios de cultura (M EA F, 1983, pp. 357-361). 
16. U ma versão relativamente amena desse cenário, mas esclarecedora, encontra-se num interessante artigo de um dosfundadores do PT sobre a marginalização dos intelectuais e do trabalho intelectual no partido, com Luiz Inácio na presidência da R epública, em que 0 autor conclui: "Entretanto, o forte pragmatismo político que nos acomete desarticulou a produção teórica sobre o pás. A agendanacional parece perdida. 0 país voltou a especializar a ação política, diminuindo o grau de influência de movimentossociaise intelectuais na construção de uma pauta de desenvolvimento" (R icci, 2003).

17. A euforia dosagentes de pastoral com 0 novo governo arrefeceu já nos primeiros meses do mandato do presidente Luiz Inácio. A atitude da CPT, como a do M ST, vem evoluindo para uma crítica aberta à orientação do novo governo em relação à reforma agrária. Com base numa atualizada e meIhor conceituação de assentado, a da família regra separa a Justiça e a sociedade brasileira, seja pela fal ta de sensi bilidade das esquerdas brasileiras em relação à questão agrária, seja pelo comodismo das elites, seja, enfim, pela efetiva falta de alternativas sociais e políticas para os desenraizados do campo, e mesmo pela incapacidade de 0 PT, de que é uma facção, compreendê-lo e incorporá-lo. Esse cenário de adversidades constitui um dos poderosos fatores para que o M ST desde a origem tendesse para o foquismo como estratégia de ação política, como forma de criar fatos políticos onde eles não parecem existir, como maneira de conduzir desalentados trabalhadores e sem-trabalho para situações de explicitação do confronto estrutural que aparentemente não há na sociedade brasileira, porque na verdade oculto.

Fora do poder, o PT valeu-se largamente do M ST como parte de sua ação para produzir uma imagem negativa do governo de Fernando H enrique C ardoso, negando e desqualificando a reforma agrária que estava em execução. N ão raro satanizou estudiosos que tentavam compreender os fatos em perspectiva diversa de sua limitada linha ideológica. A dotou 0 recurso da impugnação ideológica não só dos partidos adversários (aos quais depressa se associou partidariamente ou ideologicamente, tão logo no poder), mas também das interpretações teóricas não legitimadoras de sua ação política (não raro com o concurso de acadêmicos com domínio limitado do sistema de conhecimento que decorre da prática e da experiência dos trabalhadores que lutam pela terra) ${ }^{16}$.

O PT valeu-se do MST, ainda, para produzir-se como partido salvacionista, orientado por uma mística messiânica e mesmo milenarista, um retorno às tradições do nosso tão arraigado sebastianismo. De certo modo, a CPT tornou-se coadjuvante dessa orientação, abrindo mão da defesa dos aspectos mais ricos de sua experiência e de sua prática ${ }^{17}$. U ma espantosa renúncia, para dizer o mínimo. 0 PT no poder não tem condições políticas de apoiar o que ele próprio criou, no foquismo transgressivo que o M ST não consegue superar para alinhar-se aos propósitos e às limitações de seu próprio partido no poder. De certa maneira, o tempo dinâmico do sem-terrismo terminou, porque posto diante de um cenário de superações fora de seu domínio e de novos desafios. D e fato, isoladamente, o M ST não tem poder sobre a H istória e isso colide com a ansiosa e compreensível busca de seus militantes e de sua clientela.

A mesma dificuldade pode ser vista na situação política da C PT : membro do governo, por meio do assento que seu presidente tem no C onselho de D esenvolvimento Econômico e Social da Presidência da R epública, ao 
mesmo tempo não encontra o caminho para trazer de volta seu discurso e sua prática à normalidade institucional, com a qual está profundamente comprometida, goste ou não goste desse compromisso, fora da qual não poderá mover-se, a não ser no terreno meramente discursivo. É preocupante, para as razões de Estado, que as motivações partidárias de suas ações e intransigências no governo Fernando $\mathrm{H}$ enrique $\mathrm{C}$ ardoso não mudem de substância no governo do presidente Luiz Inácio, de que é parte. É o que fica claro nesta afirmação de D om Tomás Balduíno, sobre as ocupações de terra, praticamente falando em nome do M ST: "N a época do Fernando $\mathrm{H}$ enrique, as ocupações eram contra o governo, mas agora são a favor. São uma forma de ajudar na solução do impasse social" (Arruda, 2003a).

O u seja, a estratégia do foquismo difunde-se também no âmbito do Estado, como forma de uma suposta correção de rumos e de estabelecimento de uma governança extra-institucional. A recente medida do governo do presidente Luiz Inácio (setembro de 2003) na precocemente preocupante substituição do presidente do Instituto $\mathrm{N}$ acional de Colonização e R eformaA grária (Incra), originário da C PT, é claramente dirigida no sentido de enquadrar tanto a CPT partidária como o M ST insubmisso numa linha de cooptação política dos acordos partidários que asseguraram a ascensão do PT ao poder ${ }^{18}$. 0 impasse não foi resolvido com a eleição nem será facilmente resolvido ${ }^{19}$. O s que achavam que estavam usando uma direita frágil para chegar ao poder, descobrem-se agora esquerda frágil usada pela direita para manter o poder com mais desenvoltura, bloqueando os movimentos sociais. A lém disso, os expurgos de uma senadora, de três deputados e desse funcionário de confiança alinhado com a I greja e o M ST repetem uma sina de intolerância nos partidos de esquerda, que compromete a possibilidade de sua evolução para uma efetiva democracia.

A opção por uma ruptura ampla - uma das possibilidades - expulsaria dos empregos públicos, dos chamados cargos de confiança, os militantes que se tornaram funcionários do Estado nesses curtos meses, o que representaria não poucos problemas para eles e suas famílias. $\mathrm{N}$ a linha oposta, a opção pela conciliação eliminaria os fatores de vitalidade tanto do M ST como da CPT, pois suas estratégias são amplamente dependentes do confronto e da retórica do confronto. Tudo aquilo que teria dado certo em suas ações partidárias contra o governo Fernando $\mathrm{H}$ enrique $\mathrm{C}$ ardoso (e não deu) deixaria de dar certo contra os rumos supostamente neoliberais do governo do presidente Luiz I nácio. que estiver regularmente sobre a terra, o presidente do Incra informa, no início de outubro, que em 2003 foram assentadas 13.672 famílias. Porém, maisda metade (6.960) em projetos criados no governo anterior e apenas 6.712 em projetos do atual governo (Lopes, 2003, p. A 12). N ão só o número de assentados caiu drasticamente em relação à média anual do governo Fernando $\mathrm{H}$ enrique $\mathrm{C}$ ardoso, como nesses três quartos do primeiro ano do governo do presidente Luiz I nácio cresceu $75 \%$ o número de ocupações de terra, $161 \%$ o de acampamentose $100 \%$ o de trabalhadores mortos, conforme divulgação da CPT. Segundo seu presidente, "a mudança deve ser atribuída à expectativa de um amplo programa de re forma agrária no atual governo. 'A té agora, porém, não passamos da expectativa, porque a reforma está emperrada', diz o bispo [D om Tomás Balduíno], que tem demonstrado crescente descontentamento em relação ao governo" (Arruda, 2003c, p. A 12). 
18. Em nota sobre a demissão do presidente do Incra, a C oordenação N acional da CPT "manifesta sua perplexidade e preocupação em face da metodologiae da política expres sas nesta demissão, entregue à autoridade do ministro M iguel R os setto, do Desenvolvimento Agrário. Como metodologia, o ministro desdenhou o diálogo, reconhecida marca do presidente Luiz Inácio, visto que em momento algum procurou esclarecer possíveis dúvidas diretamente com a direção daquela autarquia. Preferiu a intervenção autoritária, violou osmais elementares princípios dos direitos da pessoa humana e acabou executando precisamente a expectativa reacioná ria da elite fundiária, a saber, a degola de $M$ arcelo $R$ esende, digno presidente do Incra" (CPT, 2003). É evidente que na composição do ministério 0 presidente atribuiu ao grupo de maior pressão uma posição secundária num âmbito político explosivo, em que a luta de classes apresenta-se em carne viva. O ptou por não
Porém, nem o M ST tem condições de sobreviver sem o governo do PT nem o PT tem condições de governar em paz sem uma conciliação com o M ST. 0 caminho encontrado também tem os seus problemas. A opção pelo repasse de verbas públicas para áreas como a educação no campo (Arruda, 2003b, p. A4) cria empregos e pode acalmar as motivações da classe média militante dos quadros da organização. Permite, também, uma ação educacional mais direta e talvez mais eficaz na área da educação rural, em que o governo geralmente atua mal e insuficientemente. $M$ as, ao mesmo tempo, representa uma renúncia do Estado às suas funções próprias e a transferência de responsabilidades de governo para 0 âmbito do que vem se configurando como Estado paralelo ${ }^{20}$ ou o que parece caminhar no sentido de uma terceirização de funções do Estado, na eventualidade de que vingue algum esquema de conciliação ${ }^{21}$. A pesar dos discursos bem intencionados, o paralelismo em relação ao Estado, por parte do MST e da CPT, constitui uma poderosa e inquietante opção pelo Estado mínimo.

0 repasse de recursos financeiros do governo para que o M ST cumpra funções que são do serviço público pode ser um modo de integrar essa organização política na estrutura, nos propósitos e nos compromissos do governo do PT, mesmo contrariando a "natureza" dessa organização. $\mathrm{N} \mathrm{a}$ prática, militantes mais ativos serão convertidos em funcionários públicos, pagospelo governo, sem responsabilidadesfuncionais, ao contrário do que é próprio do serviço público. Sem obediência aos critérios de clivagem no acesso às funções públicas, como os concursos, que foram uma conquista da sociedade brasileira no sentido de fazer do cargo público um serviço profissional ao Estado, para que deixasse de ser um serviço da dominação patrimonial, como de certo modo volta a ser nesse esquema.

Para o M ST, essa é certamente uma encruzilhada: nascido dos movimentos sociais e da vitalidade da sociedade civil num momento de impasses históricos, renuncia por esse meio a essa origem e opta pela função ambígua de não ser Estado sendo, e de ser expressão da sociedade civil não sendo. R esta saber se sobreviverá incólume a essa tentação de ser duplo numa sociedade de contradições. Essa é, também, uma encruzilhada para o governo, pois estará alimentando a transformação do M ST e seus anexos em repartição pública extra- oficial, imune aos rigores e aos controles próprios da seleção do servidor público e de sua responsabilidade formal. A falta de vontade política do governante se dissipará nessa panacéia - e a vontade política se revelará exatamente naquilo que não é. 


\section{A reforma agrária na conjuntura dos mandatos presidenciais de Fernando Henrique Cardoso}

U so aqui, portanto, o recurso metodológico do corte analítico no processo social mais amplo e mais demorado, o processo histórico, corte articulado em torno da conflitividade da questão agrária, para propor a compreensão do tema e dos dilemas relacionadoscom essa conflitivida de.Trata-se aqui de compreender sociologicamente os fatos na escala da conjuntura.

Porém, análise de conjuntura e de momentos se faz reconstituindo os processos sociais pendentes, o legado incumprido de gêneses históricas, isto é, de relações sociais problemáticas, dilemas sociais, modalidades de consciência social inquieta, demandas e questionamentos. Faz-se, também, indo além do seu tempo cronológico, antes e depois, avançando num período que é outro, mas que de algum modo permanece ou ainda não se cumpriu, registrando ali até mesmo os desdobramentos dos mesmos processos numa conjuntura nova, cujas sinalizações são diversas da quela que constitui o foco da análise.

É isso que faço aqui: recolho o elenco de processos sociais pendentes na conjuntura da análise e examino complementarmente 0 desenrolar desses processos no que poderá ser a conjuntura subseqüente. $E$ faço-o por meio de seus protagonistas mais visíveis, como a I greja, a C PT, o M ST, a C ontag, os governos. $\mathrm{N}$ a verdade, estamos em face de processos sociais e políticos inacabados.

A conjuntura é um momento da circunstância histórica e social. $\mathrm{N}$ em toda mudança de governo define uma nova conjuntura social e histórica. $\mathrm{M}$ as neste caso, $\mathrm{O}$ governo de Fernando $\mathrm{H}$ enrique $\mathrm{C}$ ardoso defrontou-se com uma herança política e de políticas sociais discrepante em relação aos eixos definidores de sua ação e de seu partido. É o que permite pensar na especificidade do período, na perspectiva de um recorte de natureza metodológica.

Basicamente, seu governo herdou o aparato institucional e legal que a ditadura estabelecera e legara para canalizar as tensões sociais do campo nos parâmetros da ordem republicana e da sociedade de classes e que subsistira ao longo de uma tumultuada sobrevivência de quase dez anos. H erdou, ainda, a multiplicação de ocupações de terra e da demanda de reforma agrária, a partir do fim do regime militar, e o correlato recuo do governo Sarney no trato das pressões pela reforma. H erdou o recuo legal atribuir àala católica do PT funçõesdecisivasna ação governamental.

19.0 utra evidência dessas dificuldades pode ser observada em relação ao programa Fome Zero. Embora concebido por José Graziano da Silva, Dom M auro M orelli, do Conselho de SegurançaA limentar, era 0 nome politicamente mais provável para dirigi-lo. M as não foi o indicado. Em artigo assinado, comenta: "Além da burocracia que amargura a vida dosgovernantese muito mais do povo, nos palácios se aninham as víboras das intrigas e maledicências. R ixase disputas de poder solapam projetose fazem ruir as esperanças do povo. 0 bom ministro do combate à fome foi empurrado pelos seus assessores mais diretos para o caminho que percorreu. De modo especial, gostaria de entender por que 0 assessor religioso do presidente se meteu numa seara onde jamais trabaIhou" (M orelli, 2003).

20. $\mathrm{N}$ a linguagem das chamadas organizações populares, o Estado pa- 
ralelo édesignado como poder popular, o que é também umaindicação do popular como fonte de legitimidade.Tra ta-se de cópia de instituição cubana; lá uma instituição dócil, mero acessório do regimepolítico, sem nenhuma função ativana construção do que poderia ser definido como uma sociedade nova e democrática.

21. Em palestra a lideranças de movimentos sociais, em Maceió, João Pedro Stédile demonstra que o M ST tem clareza quanto ao bifrontismo do PT no governo:"O Lula, como representante da classe trabalhadora, é favorável ao projeto popular que defendemos. M as o presidente Luiz I nácio não, porque é fruto de uma composição que 0 transformou em um produto transgênico." E mais adiante:" 0 governo do presidente Luiz Inácio não tem uma posição unitária sobre qual caminho seguir, há ministros neoliberais, ministros recicladorese ministroscomprometidoscom o projeto popular" (R odrigues, 2003, p. A9). representado pelo alargamento do conceito de terra produtiva na C onstituição de 1988, uma clara resposta às ações do M ST na sua tática política do confronto, a sua política impolítica, um fator de bloqueio da reforma agrária: até desmatamento predatório passou a ser considerado uso produtivo da terra.

H erdou, também o desassossego social derivado de uma interpretação do legado da reforma agrária ditatorial muito além de suas balizas e de suas possibilidades. Para diferentes protagonistas do conflito agrário, a reforma agrária passou a ser interpretada como um convite à conflitividade. O governo militar supostamente não teria aplicado o Estatuto da Terra, difundindo-se a palavra de ordem de que era preciso "tirar a reforma agrá ria do papel" , o que tampouco correspondia ao que acontecera: a reforma entrara em processo e fora feita durante o regime autoritário em consórcio com a Lei de Segurança N acional, como recurso de desativação de tensões que pudessem servir de caldo de cultura para a ação subversiva dos partidos clandestinos.

Em suma, o governo Fernando Henrique $\mathrm{C}$ ardoso herdou a desordem de uma demanda fora dos parâmetros da institucionalidade e de um Estado com orientações desencontradas e confusas em relação à reforma agrária. O s episódios de Corumbiara e Eldorado de Carajás foram expressões dessa herança. D esordem, também, porque os grupos políticos que assumiram a tutela da demanda pela reforma eram constituídos por ativistas da campanha do candidato derrotado à presi dência e não estavam dispostos a abrir mão de um trunfo partidário e eleitoral em favor de uma reforma agrária que não fosse a "sua”. E ssa conduta foi observada durante os oito anos de mandato, mesmo quando o governo de Fernando $\mathrm{H}$ enrique $\mathrm{C}$ ardoso, com a nomeação de $\mathrm{R}$ aul Jungmann, mais se aproximou das reivindicações da I greja, da C PT, do M ST e do próprio PT nessa questão. $M$ ais até do que hoje se aproxima o governo de Luiz Inácio.

Portanto, a política agrária de Fernando Henrique Cardoso teve por objetivo fazer a reforma e ao mesmo tempo instituir a normalidade do conflito, isto é, definir as bases institucionais do conflito agrário, fazendo do Estado o mediador e gestor das soluções. A M edida Provisória que proíbe vistorias para reforma agrária em terras invadidas, mantida pelo governo do PT, propôs-se como o inevitável instrumento do Estado administrador da ordem ${ }^{22}$. A política agrária de Fernando H enrique $C$ ardoso foi no sentido de distribuir a terra e distribuir a paz social, ao mesmo tempo, atenuando e reduzindo a conflitividade dos confron- 
tos sociais que tem a disputa pela terra como causa. A criação da 0 uvidoria A grária, entregue a um reputado e competente desembargador, mantido pelo novo governo, foi certamente medida das mais acertadas numa linha política de conciliação e prudência, com reconhecidos resultados na pacificação do campo.

U m aspecto essencial de como o governo de Fernando $\mathrm{H}$ enrique C ardoso propôse executou sua política agrária diz respeito à clara consciência do presidente de que a questão agrária não se apresentava nem se apresenta solitariamente no elenco dos problemas a resolver. A questão agrária é, no Brasil, como em tantas outras partes do mundo, também uma questão política, pelo conjunto de interesses sociais e políticos que acumulou na definição e na sustentação das classes dominantes, particularmente os setores que expressam os interesses relativos à propriedade da terra. 0 Brasil tradicional e arcaico da dominação patrimonial, do clientelismo político, do coronelismo, é também um produto do regime fundiário e parte da questão agrária. $\mathrm{N}$ ão fosse assim, a reforma teria sido feita e concluída há muito tempo. Por isso mesmo, seu governo adotou um conjunto de procedimentos orientados claramente a minar a dominação patrimonial e o clientelismo político, interrompendo a circularidade de suas influências na sustentação da estrutura do Estado (C ardoso, 1994, pp. 39-41). CPT e M ST e as esquerdas em geral não se interessaram por esse aspecto essencial do processo político e do momento histórico, sem o qual a reforma agrária tem pouco ou nenhum sentido. É essa despreocupação que dá às ações desses setores a conotação de ações pré-políticas, inseridas na lógica da sociedade tradicional e arcaica.

$\mathrm{N}$ a outra ponta do período conjuntural, o governo do presidente Luiz Inácio, apenas começado, propôs-se a atuar tomando como referência eixos proclamados como substancialmente diversos. 0 s fatos, obviamente, fal am mais do que a retórica da prática oposicionista do PT e da campa nha eleitoral, e dizem que as realizações estão incrivelmente aquém da retórica, das promessas e dos planos fundados na condenação expressa e veemente do que o governo anterior fazia e fez. Embora, de certa maneira, o PT tenha se proposto a fazer o oposto, está de fato fazendo o mesmo. E no que diz respeito à reforma agrária está fazendo também o menos, completamente bloqueado por seus próprios aliados, à espera de um Pla no $\mathrm{N}$ acional de R eforma A grária que supostamente tinha e que de fato não tem ao final do primeiro ano do governo, a não ser um esboço de procedimentos $\mathrm{s}^{23}$. N um caso assim, é tempo demais.
Pode-se dizer, no entanto, para usar a mesma metáfora, que a transgenia alcançou também asorganizações que instituíram uma tutela partidária sobre os movimentos sociais e as demandas populares, como o próprio M ST, divididas e inseguras entre a condição de agentes da sociedade civil e a de agentes de um partido político que é agora governo e Estado. De qualquer modo, essas organizações têm um projeto político e um projeto de Estado, como sempre ficou claro. D o mesmo modo que há muito tempo, desde antes de ser presidente, Lula tem proclamado, e jána presidência voltou a fazê-lo, que não é um homem de esquerda. Isso, basicamente, diz apenas que o presidente da R epública não se assume como agente de um projeto político que transforme o Estado paralelo em Estado oficial. Trata-se, pois, de um cenário em que os impasses poderão durar todo o período de governo do PT, com sérios danos para os programas sociais como 0 da reforma agrária. 
22. Sobre as diferentes medidas do governo Fernando $\mathrm{H}$ enrique $C$ ardoso nesse sentido e uma compreensão de conjunto da identidade e da ação dos participantes na luta pela reforma agrária, cf. Jungmann (2003).

23. "O presidente do Instituto Nacional de Colonização e R eformaAgrária(Incra), R olf $H$ ackbart, divulgou ontem em Braślia o número oficial de assentamentos feitos em 2003. Foram beneficiadas36.301 famílias, segundo $\mathrm{H}$ ackbart, que se vangloriou: disse que o governo superou a meta de 30 mil famílias, prevista no Plano $\mathrm{N}$ acional de $\mathrm{R}$ eforma A grária. $N$ a verdade, a metade de 30 mil foi definida no último trimestre do ano. No primeiro semestre, o governo havia prometido chegar à marca de 60 mil novos assentamentos" (Arruda, 2004, p. A9).
Particularmente importante na compreensão das orientações do governo do PT e do que o distancia do governo anterior é o fato de que regenera o clientelismo e a troca de favores como prática política no âmbito das funções do comando da política agrária, em detrimento dos funcionários de carreira. $\mathrm{N}$ ão se dá conta de que a falta de critério nesse particular fortalece os agentes políticos do B rasil arcaico e compromete a amplitude de reformas estruturais como a reforma agrária.

Em resumo, são, portanto, essas as balizas de compreensão sociológica da conjuntura agrária que tem seu núcleo significativo no governo Fernando $\mathrm{H}$ enrique $\mathrm{C}$ ardoso com empenhos no sentido de que o Estado, num cenário de pressões e imposições, optou por construir sua própria estratégia de inserção da questão agrária e da demanda de reforma agrária na sua agenda política. Contrapôs-se, portanto, à recusa do diálogo e ao extenso e disseminado aparato de pressão política representado pelo M ST e pela CPT, redefinindo-se para ter sua própria doutrina de reforma agrá ria. 0 s problemas que o governo do presidente Luiz Inácio vem tendo com essas entidades sugere justamente a vitalidade dessa agenda e as dificuldades dos que se opõem a ela. Contribuiu para a definição de um rumo próprio do governo Fernando $\mathrm{H}$ enrique $\mathrm{C}$ ardoso na questão agrária a intolerância do M ST e da C PT. R eiteradamente convidados a participar da elaboração da política agrária de um governo que estava disposto a viabilizar propostas e a incorporá- las amplamente, recusaram- se, preferindo, na melhor das hipóteses, eventual mente, a via da informalidade e da denúncia. U ma modalidade de vigilantismo adverso à própria causa que tem, de qualquer modo, a sua importância na definição de políticas públicas. Com a desvantagem de que quem denuncia deixa de ser ativo protagonista da solução, perdendo-se no meio do caminho do que deveria ser 0 ato político inteiro. Essas organizações, infelizmente, se imobilizam no cumprimento da hipotética pauta de um governo que não existe. $E$ deixam de prestar na sua inteireza, aos trabalhadores da terra, o enorme serviço que poderiam prestar.

Sua opção foi a de utilizar a questão agrária como um tema de oposição sistemática que viabilizasse a ascensão política do PT. Procuraram não se comprometer com o governo, já que estavam, de fato, comprometidas com o PT, o que se entende, sendo facções partidárias de oposição ao partido então governante. Difícil de entender quando fazem oposição ao governo de seu próprio partido, como vem ocorrendo desde a posse do presidente Luiz Inácio. N ão compreenderam, portanto, o caráter historicamente 
suprapartidário da reforma agrária e que os interesses urgentes dos traba Ihadores rurais eram mais amplos e significativos do que os de um partido político que, justamente por adotar essa visão, tinha por sua urgência uma pressa menor e eleitoral.

Com isso, de certo modo prejudicaram a reforma agrária sem ter de fato acumulado energia política para contrapor proposta diversa e meIhor, como se vê agora no governo do presidente Luiz Inácio. M as a intransigência dessas duas organizações ajudou poderosamente o governo Fernando $\mathrm{H}$ enrique $\mathrm{C}$ ardoso a se propor como mediador e executor de uma reforma agrária democrática. 0 s que temiam a reforma, até mesmo na Igreja, dispuseram-se a aceitá-la nas ações do equilíbrio sensato do governo, como alternativa à ideologia aparentemente anárquica e à prática iconoclasta que se anunciava e tem se anunciado cada vez mais nas organizações que fizeram oposição à reforma agrária de Fernando H enrique $\mathrm{C}$ ardoso.

B oa parte dos problemas e da dificuldade do diálogo vem da incompreensão de que as referências estruturais e fundamentais de um programa brasileiro de reforma agrária foram estabelecidas pela direita e não pela esquerda. E que mesmo governos de esquerda só poderão atuar a partir delas. Foi a direita que deu o golpe de Estado em 1964, a isso levada por opor-se radicalmente à bandeira de reforma agrária das esquerdas. $0 \mathrm{~s}$ grandes proprietários de terra foram protagonistas privilegiados do cenário do golpe. $M$ as a legitimidade da pressão por reforma agrária foi nesse ato reconhecida. Como é da tradição brasileira, uma grande transformação de natureza social e política levada a efeito por seus opositores.

Além disso, o fim da ditadura não foi uma vitória de esquerda, mas vitória da ampla coalisão política pela democracia e pelo Estado de direito, que reuniu um largo espectro de posições políticas, da direita à esquerda, e forte equilíbrio nas posições de centro. A eleição do presidente Luiz Inácio tampouco indica uma reorientação nessa tendência em torno do centro: ele foi eleito pelo voto populista e não apenas pelo voto petista. 0 bifrontismo dessa eleição manifesta-se claramente no recuo do governo em relação a promessas e programas, em particular no que se refere à reforma agrária: o populista que há no presidente pode pôr o boné do M ST, mas não pode tirar o barrete frígio da R epública para o M ST.

As duas grandes questões estruturais e históricas da sociedade brasileira - o trabalho escravo e a propriedade da terra -, na distância de pouco mais de um século em relação à Lei de Terras, de 1850, não foram 
equacionadas e resolvidas pelos grupos progressistas ou de esquerda até 0 encerramento do intervalo democrático de 1946 a 1964. Ao contrário, foram definidas e encaminhadas institucionalmente pelos grupos conservadores ou de direita que se apressaram a conduzi-las nos diferentes e respectivos momentos da necessidade histórica da reforma nas relações de trabalho e nas relações de propriedade, aos limites de seus próprios parâmetros. Esses dois eixos de solução de contradições da sociedade brasileira foram pactuados historicamente de modo não pacífico entre os opostos. $\mathrm{N}$ esses pactos implícitos, os dois problemas são definidos como problemas suprapartidários, que efetivamente 0 são, e suprapartidárias as soluções e a gestão das soluções. Com o inconveniente de que os principais formuladores do problema se ausentam do processo por não compreenderem a realização de um projeto nos limites de sua possibilidade histórica.

Ciente dos limites desse pacto e único modo de viabilizar, ampliar e reformar a reforma agrária fora da pauta herdada da ditadura, o governo Fernando $\mathrm{H}$ enrique $\mathrm{C}$ ardoso optou por entregar a execução da reforma a funcionários e técnicos de carreira. Em boa parte foi essa decisão que confirmou na atuação do ministro $R$ aul Jungmann a reforma agrária como política de Estado e não meramente como política de partido. Aliás, para o PSD B, a questão agrária nem mesmo chegou a existir e a reforma agrária de Fernando $\mathrm{H}$ enrique $\mathrm{C}$ ardoso não teve $\mathrm{o}$ apoio de seu partido e foi até impugnada por seus ideólogos. 0 presidente assumiu pessoalmente, como magistrado, a reforma agrária como solução de um problema estrutural da sociedade brasileira, justamente porque tinha dela uma compreensão política mais ampla do que a mera compreensão econômica (C ardoso, 1994, pp. 39-41). N ão fosse isso, não teria promovido assentamentos e regularizações fundiárias de mais de meio milhão de famílias de trabalhadores rurais nos oito anos de seu governo. Aliás, o apoio político tácito que o governo teve para realização da reforma representou 0 apoio à reforma agrária como instrumento da ordem, contra a reforma agrária transgressiva, temida pelas incertezas institucionais que gera.

Jungmann tomou outra decisão fundamental, que teria sido inviável se levada adiante fora dos parâmetros herdados para realização da reforma agrária. A nulou os títulos de propriedade relativos a uma área de $93 \mathrm{mi}-$ Ihões de hectares, dando prazo para que os portadores de títulos legítimos os apresentassem ao governo para terem a anulação cancelada. Titulares de sessenta milhões de hectares não conseguiram regularizar sua situação e tiveram seus documentos invalidados. Essa medida teria sido impossível 
sem o concurso dos funcionários de carreira e sem o efetivo apoio social e político à reforma.

A decisão deu visibilidade a um processo silencioso que ocorre no B rasil desde a $R$ evolução de 30: a anulação parcial dos efeitos da Lei de Terras de 1850, retomando o Estado, o mais extensamente possível, o domínio do território, para se propor assim como gestor da função social da propriedade. 0 s direitos plenos que a Lei de Terras transferira aos proprietários vêm sendo diminuídos desde a promulgação do C ódigo de Á guas, no governo Vargas, pelo qual o subsolo retorna ao domínio do Estado e deixa de ser abrangido pelo direito de propriedade. 0 mesmo se deve dizer da legislação de proteção ao patrimônio histórico, da legislação de proteção e preservação dos territórios indígenas, da legislação florestal, da legislação ambiental e do próprio Estatuto daTerra.Todas essas medidas estabeleceram restrições ao exercício do direito de propriedade, a ele sobrepondo funções sociais. R estrições que, aliás, também valem para os pequenos proprietários e para a agricultura familiar.

$\mathrm{N}$ o meu modo de ver, o governo Fernando $\mathrm{H}$ enrique $\mathrm{C}$ ardoso atuou no sentido de dar visibilidade política a esse processo e de confirmá-lo, por meio das medidas que tomou num capítulo da história fundiária brasileira literalmente ignorado. A criação de um M inistério Extraordinário da R eformaA grária, separado e independente do M inistério da A gricultura, constituiu-se de fato na criação de um gestor político autônomo da função social da propriedade que se sobrepõe ao gestor técnico da partição da terra, que é o Incra. 0 governo do presidente Luiz I nácio reverteu esse processo ao nomear um gestor político para o Incra, que esvaziou a função do ministro e ao mesmo tempo rompeu o pacto republicano que havia no caráter suprapartidário da questão e da reforma agrária. Q ue esse gestor tenha sido demitido em seguida, indica com clareza dentro de que limites propõe-se a questão agrária, tanto para a direita como para a esquerda. $\mathrm{N}$ a verdade, ainda não está claro se o governo avançará, nem como avançará, na questão da retomada do domínio do território e do senhorio do Estado sobre ele, condição fundamental para que de fato se assuma como agente da função social da propriedade.

0 cenário é, portanto, um cenário dramático. 0 s protagonistas não se entendem e ao mesmo tempo desfazem a institucionalidade da reforma agrária. 0 amplo espaço de exercício de criatividade social e econômica que o governo anterior legou ao seu sucessor, e que o M ST é que tem a melhor competência para aproveitar, está sendo minado pelo próprio M ST 
e pela C PT. Se insistirem na ação de representantes de um fictício Estado paralelo (ou poder popular, como o definem algumas organizações) e renunciarem à função em aberto de ativistas da sociedade civil, apenas ampliarão o elenco de impasses do novo governo, ao mesmo tempo que destruirão, como estão destruindo, o legado positivo do governo Fernando $\mathrm{H}$ enrique $\mathrm{C}$ ardoso. A conduta de ser do contra para impugnar este e apoiar aquele não leva em conta os nexos políticos inevitáveis nos programas de reforma social que atendem necessidades suprapartidárias, como este programa.

U m ano já está perdido. 0 governo nem mesmo conseguiu dar mera continuidade ao programa agrário do governo anterior, que poderia ser reformado - a reforma na reforma - na própria execução. Ao mesmo tempo, essas organizações atuam no sentido do óbvio debilitamento da sociedade civil, cujas funções políticas têm dificuldade para compreender. U ma dupla perda. A espantosa multiplicação de organizações políticas de sem-terra - 75 já neste momento - indica uma tendência ao esvaziamento do M ST, apesar de ainda conservar uma relativa força em conseqüência de seus vínculos com a I greja e do óbvio reforço que lhe oferece o próprio governo. É o que lhe dá a ilusão do poder que nunca teve nem precisa ter para prestar um serviço histórico aos trabalhadores rurais e à sociedade brasileira.

\section{Referências Bibliográficas}

Anton IAZZI, Pe. Alberto. (s.d.), A I greja C atólica e a situação política. D isponível em http:/ / www.cnbb.org.br/ estudos/ encar641.html.

Arruda, R oldão. (2003a), “N a economia, 120 km por hora; no social, só 20” . 0

Estado de S. Paulo, 27/ 6 (edição eletrônica).

.. (2003b), "Governo reabre os cofres e dá fôlego ao M ST" . 0 Estado de S.

Paulo, 5/ 10, p. A4.

. (2003c), "O cupações no governo do presidente Luiz I nácio crescem 75\%".

0 Estado de S. Paulo, 11/ 10, p. A 12.

. (2004), "Incra assenta menos famílias que o previsto", 0 Estado de S. Paulo,

$17 / 1$, p. A9.

B o fF, Leonardo. (1981), Teologia à escuta do povo. Petrópolis,Vozes (separata da R evista

E clesiástica B rasileira, vol. 41, fasc. 161, mar.).

Botas, Paulo C ezar Loureiro. (1983), A bênção de abril: "B rasil, U rgente", memória e engajamento católico no B rasil, 1963-1964. Petrópolis, Vozes. 
C AR do so, Fernando H enrique. (1985a), A democradia necessária. C ampinas, Papirus. . (1985b), E ntrevistas a L ourenço D antas M ota. B raślia, Senado Federal - C entro Gráfico.

. (1994), 0 presidente segundo o sociólogo: entrevista de F ernando H enrique C ardoso a R oberto Pompeu deToledo. São Paulo, Companhia das Letras.

C N BB - Conferência N acional dos Bispos do Brasil. (1976), Pastoral da terra. São Paulo, Edições Paulinas.

C N BB - Conferência N acional dos Bispos do Brasil. (1980), I greja e problemas da terra. São Paulo, Edições Paulinas. Disponível também em http:// www.dhnet.org.br/ direitos/ sos/ terra/ cnbb_terra.html.

C ASALdÁligA, D om Pedro. (1971), U ma igreja da A maz ônia em conflito com o latifúndio e a marginaliz ação social. São Félix (MT), s.e.

CPT - Comissão Pastoral daTerra. (2003), G olpe na reforma agrária. G oiânia, 3/ 9, s.e.

D E K ADT, Emanuel. (1970), C atholic radicals in B razil. Londres, $O$ xford U niversity Press.

Della C aVA, R alph. (1986), “A I greja e a abertura, 1974-1985”. In: K R ISH KE, Paulo \& M AIN WARIN G, Scott (orgs.). A igreja nas bases em tempo de transição (1974-1985), Porto Alegre, L\&PM .

DreIFUSS, R ené Armand. (1981), 1964: a conquista do Estado: ação política, poder e golpes de dasse. 2. ed., Petrópolis, Vozes.

F OLHA DO A mAPÁ. (2003), “Começam mobilizações para o Tribunal do Latifúndio no Pará". F olha do A mapá, M acapá, $7 / 10$ (edição eletrônica).

G naccar IN I, José C ésar. (1980), Latifúndio e proletariado. São Paulo, Polis.

H eller , A gnes. (1978), L a théorie des besoins chez M arx. Paris, U nion Générale d'Éditions (trad. $M$ artine $M$ orales).

Jun Gm an n , R aul. (2003), "Sob o signo da foice e da cruz" . Primeira L eitura, 11: 110121, jan., São Paulo.

K atTAH, Eduardo. (2003), "Frei Betto critica 'bandidos' que atacam sem-terra". 0 E stado de S. Paulo, 5/ 7 (edição eletrônica).

LAM BeRT, Jacques. (1959), 0 s dois B rasis. $R$ io de Janeiro, IN EP - M inistério da Educação e C ultura.

LeR R ER , D ébora. (1998), 0 som do silêncio das versões da praça. D issertação de mestrado, São Paulo, Escola de Comunicação e A rtes da U niversidade de São Paulo.

Lo PES, E ugênia. (2003), "R eforma não excluirá invasores, diz H ackbart” . 0 E stado de S. Paulo, 11/ 10, p. A 12 .

M aest RI, M ário. (1999), “N atalino faz vinte anos”. N on. Portugal. Disponível em http:/ / zonanon.com/ non/ plural/ doc27.html.

M ARTIN S, José de Souza. (1980), "Terra de negócio e terra de trabalho: contribuição 
para o estudo da questão agrária no Brasil". In: Expropriação e violência: a questão política no campo, São Paulo, H ucitec, pp. 45-66. . (2003), 0 sujeito oculto: ordem e transgressão na reforma agrária. Porto Alegre, Editora da U niversidade Federal do R io Grande do Sul.

MEAF - M inistério Extraordinário para Assuntos Fundiários. (1983), C oletânea. Brasília.

M ÉlIGA, Laerte D orneles\& JAN SO N , M aria do C armo. (1982), E ncruzilhada N atalino. Porto A legre,Vozes/ Escola Superior de Teologia São Lourenço de Brindes. M or elli, M auro. (2003), "O caminho das pedras". F ol ha de S. Paulo, 15/ 3 (edição eletrônica).

M o u R A, M argarida M aria. (1988), 0 s deserdados da terra: a lógica costumeira e judicial dos processos de ex pulsão e invasão da terra camponesa no sertão de $M$ inas $G$ erais. $R$ io de Janeiro, Bertrand Brasil.

N ISBET , R obert. (1969), L a formadión del pensamiento sociológico. BuenosAires, A morrortu Editores, vol. 1 (trad. Enrique M olina deVedia).

O L iberal. (2003), "TJE condena julgamentos simbólicos”. 0 Liberal, Belém, 27/ 10 (edição eletrônica).

O LIVEIR A, A riovaldo U mbelino de. (2004), "Entrevista". M ST I nforma, ano III, 55, São Paulo, 16/ 1 (edição eletrônica).

R ıccı, R udá. (2003), "O s intelectuais e a política lulista”. R evista E spaço A cadêmico, 29, out. D isponível em http:/ / www.espacoacademico.com.br/ 029/29ricci.htm. R ODRIGUES, Ricardo. (2003), "Stédile diz que presidente virou 'transgênico'". 0 Estado de S. Paulo, 8/ 10, p. A9.

SALES, D om Eugênio de Araújo. (1960), "A Igreja e a reforma agrária brasileira". Síntese Política, E conômica, Sodal, ano II, 7, jul.- set., R io de Janeiro.

Sch mitter , Philippe C. (1971), Interest conflict and political change in B razil. Stanford, Stanford U niversity Press.

SkIn n ER , Q uentin. (2000), A s fundaçoes do pensamento político moderno. 2. reimp., São Paulo, C ompanhia das Letras (trad. R enato Janine R ibeiro e LauraTeixeira M otta). So uza, Percival de. (2000), A utópsia do medo. R io de Janeiro, G lobo.

StÉdILE, João Pedro. (2002), “L andless battalions: the SemTerra movement of Brazil”. $\mathrm{N}$ ew L eft R eview, 15: 77-104, maio-jun., Londres.

TH OM PSO N E. P. (2002), C ostumes em comum: estudos sobre a cultura popular tradicional. 1. reimp., São Paulo, C ompanhia das Letras (trad. R osaura Eichemberg). 


\section{Resumo}

Já no primeiro mandato do presidente Fernando $\mathrm{H}$ enrique C ardoso, a política agrária sofreu reorientações significativas, que marcariam seu segundo mandato, a partir da nomeação de $R$ aul Jungmann como ministro do Desenvolvimento Agrário. A reforma agrária final mente encontrou o seu sujeito, a agricultura familiar, e o Estado encontrou a sua missão agrária como gestor do território. Foram assim estabelecidas as bases concretas para o exercício da função social da propriedade, recuperando 0 Estado, na prática, o domínio eminente do território do país. I mportante providência nesse sentido foi a anulação dostítulos irregulares de propriedade de sessenta milhões de hectares de terra. 0 governo firmou a prerrogativa do Estado de "rotinizar" a redistribuição da terra concentrada e regular e assegurar o direito de propriedade em associação com a dupla alternativa de dois modelos agrícolas conviventes: o agronegócio e a agricultura familiar.

Palavras-chave: R eforma agrária; Tensões sociais; I greja C atólica; A gricultura familiar.

\section{Abstract}

D uring Fernando H enrique C ardoso'sfirst term in office, the agrarian policy underwent significant changes that marked his second term, as of when $\mathrm{R}$ aul Jungmann was appointed $M$ inister of Agricultural D evelopment. Agrarian reform finally encountered its subject, subsistence crop farming, and the State found its agrarian mission as manager of the territory.T hus, the concrete foundationsfor the exercise of the social function of landownership were established, and the State recovered, in practice, the eminent domination of the country's territory. 0 ne of the important provisions was the annulment of irregular land deeds regarding 60 million hectares. The government determined it to be the prerogative of the State to make routine redistribution of concentrated land and to regulate and assure landownership rights associated to the double alternatives of two cohabitating agricultural models: agro-business and subsistence farming.

Key words: A grarian policy; Social unrest; C atholic C hurch; Subsistence farming.
José de Souza M artins é professor titular aposentado do Departamento de Sociologia (FFLCH-USP); fellow deTrinity $\mathrm{H}$ all e professor titular da Cátedra Simón Bolívar da U niversidade de Cambridge (1993-1994); membro da Junta de Curadores do Fundo Voluntário das $\mathrm{N}$ ações U nidas contra as Formas C ontemporâneas de Escravidão. 